\title{
PENYELESAIAN WICARA MELALUI PERADILAN OLEH MAJELIS UTAMA DESA PAKRAMAN (MUDP) PROVINSI BALI
}

\author{
Oleh : \\ I Made Somya Putra ${ }^{1}$
}

\begin{abstract}
This study aim to describe and analyze in debt about the basic authority in resolving Main Assembly of Pakraman Village or Majelis Utama Desa Pakraman (MUDP) Bali Province speech by justice and how to talk through the judicial settlement process by MUDP Bali Province. This research used normative legal research based legal document research and library research. The conclusion in this study, that authority obtained MUDP Bali to finish the speech obtained a mandate by Council Decision No. 050 Main Pakraman / Kep / Psm1 / MDP Bali / III / 2006 concerning the results of the Great Pasamuhan I MDP Bali and Completion of speech through the courts by MUDP Bali has been arranged by the Decision of the MDP Bali Number: 002 /Skep / MDP Bali / IX / 2011 on the Implementation Guidelines and Technical Guidelines Speech by Assembly Resolution Pakraman (MDP) Bali as a form of autonomy that is owned by Pakraman.
\end{abstract}

Keywords: Dialogue, Justice, Main Assembly of Pakraman Village (MUDP) Bali Province

\section{PENDAHULUAN}

\subsection{Latar Belakang Masalah}

Berdasarkan Pasal 1 Angka 4 Peraturan Daerah (Perda) Nomor 3 Tahun 2001 sebagaimana diubah dengan Perda Nomor 3 Tahun 2003 Tentang Desa Pakraman (selanjutnya disebut Perda Desa Pakraman), Desa Pakraman ${ }^{2}$ memiliki hakhak tradisional. Salah satu hak tradisional

Peneliti adalah Mahasiswa Program Studi Magister (s2) Ilmu Hukum, Jurusan Hukum Dan Masyarakat, yang berprofesi sebagai Praktisi Hukum (Advokat), berkantor di Lembaga Advokasi Dan Bantuan Hukum Indonesia (LABHI)-Bali, Alamat Jln. Pulau Buru, No.3, Blog : lawyersinbali.wordpress.com, E-Mail : somyaputra@gmail.com, Hp.081805585011.

2 Desa pakraman adalah kesatuan masyarakat hukum adat ( KMHA) di Propinsi Bali yang mempunyai satu kesatuan tradisi dan tata krama pergaulan hidup masyarakat umat Hindu secara turun temurun dalam ikatan kahyangan tiga atau kahyangan desa yang mempunyai wilayah tertentu dan harta kekayaan sendiri serta berhak mengurus rumah tangganya sendiri (Baca : Peraturan Daerah (Perda) Nomor 3 Tahun 2001 sebagaimana diubah dengan Perda Nomor 3 Tahun 2003 Tentang Desa Pakraman).
Desa Pakraman adalah membuat awigawig, ${ }^{3}$ di samping menyelenggarakan pemerintahan sendiri, serta menyelesaikan persoalan-persoalan hukum yang terjadi di wilayahnya, baik yang berupa sengketa ataupun pelanggaran adat.

Dalam perkembangannya kemudian Desa Pakraman memiliki beberapa masalah yang tidak semua dapat diselesaikan secara internal Desa Pakraman. Untuk itulah diperlukan suatu keputusan Majelis Utama Desa Pakraman (MUDP) Provinsi Bali untuk menyelesaikan perkara adat tersebut. Berdasarkan Pasal 14 Perda Desa Pakraman, Majelis Desa Pakraman (MDP) Provinsi Bali yang berkedudukan di ibu kota propinsi disebut Majelis Utama Desa Pakraman

I Wayan Surpha memberikan pengertian awig-awig yaitu berupa peraturan yang mengatur pergaulan hidup untuk mewujudkan tata kehidupan yang ajeg dalam masyarakat (baca : I Wayan Surpha, 1993, Eksistensi Desa Adat di Bali, Penerbit PT. Upada Sastra, Denpasar, hlm.26). 
(MUDP) yang merupakan MDP yang memiliki tingkat tertinggi diatas Majelis Madya Desa Pakraman (MMDP) yang berkedudukan di ibukota kabupaten/kota, dan Majelis Alit Desa Pakraman ( MADP), berkedudukan di ibukota kecamatan.

Pasal 16 dan Ayat (1) dan Ayat (2) Perda Desa Pakraman mengatur tentang Tugas dan wewenang MDP Provinsi Bali. Khusus untuk masalah penyelesaian kasuskasus adat Kewenangan MUDP Provinsi Bali hanyalah sebagai penengah saja untuk kasuskasus adat murni yang tidak terselesaika pada tingkat desa, namun ternyata MDP Provinsi Bali tidak hanya menjadi penengah saja, tetapi juga sebagai pemutus dalam perkara adat. Perkara adat yang bukan termasuk dalam perkara perdata maupun pidana, namun termasuk perkara adat murni di Bali kemudian disebut dengan wicara. ${ }^{4}$

Dari uraian tersebut di atas, Keputusan MUDP Provinsi Bali tersebut ternyata memiliki kontroversi dari aspek yurisdis dimana dalam realita MUDP Provinsi Bali sudah menyelesaikan wicara dengan cara memutus bukan menengahi atau melakukan mediasi, sementara dalam aturan hukum yang tersedia, MUDP Provinsi Bali hanya berwenang menengahi sengketa adat atau wicara saja bukan untuk memutus, itupun terbatas pada sengketa sebagaimana tercantum dalam Pasal 16 Perda Desa Pakraman.

Wicara atau perkara adat adalah perkara yang muncul karena sengketa adat atau pelanggaran norma hukum adat Bali, baik tertulis maupun tidak tertulis (catur dresta) yang dijiwai oleh nilai-nilai agama Hindu, yang tidak termasuk sengketa perdata dan/atau pelanggaran hukum menurut hukum negara (Baca : Majelis Desa Pakraman, 2012, Purwaka Tata Cara Penyelesaian Wicara Oleh Majelis Desa Pakraman (MDP) Bali Cet-I, Majelis Utama Desa Pakraman (MUDP) Bali, Denpasar).

\subsection{Rumusan Masalah}

Dari latar belakang yang telah disajikan tersebut, maka dapatlah dikemukakan rumusan masalah, antara lain :

\subsubsection{Apa dasar kewenangan MUDP Provinsi Bali dalam menyelesaikan Wicara melalui Peradilan?}

1.2.2 Bagaimana proses penyelesaian wicara melalui peradilan oleh MUDP Provinsi Bali?

\subsection{Tujuan Penelitian}

Tujuan penelitian dalam penelitian ini dibedakan menjadi tujuan umum dan tujuan khusus. Adapun penjelasan masing-masing tujuan dimaksud adalah :

\subsubsection{Tujuan Umum}

Tujuan umum penelitian ini adalah untuk memahami dan mengetahui tentang aspek hukum Penyelesaian Wicara baik yang bersumber dari hukum adat maupun ketentuan peraturan perundang-undangan dalam rangka mewujudkan ketertiban, keamanan dan kedamaian wilayah Bali, khususnya wilayah Desa Pakraman.

\subsubsection{Tujuan khusus}

1. Untuk memahami dan menganalisis dasar kewenangan MUDP Provinsi Bali dalam menyelesaikan Wicara melalui peradilan.

2. Untuk mengetahui dan mengAnalisis proses penyelesaian Wicara melalui peradilan oleh MUDP Provinsi Bali.

\section{METODE PENELITIAN}

Penelitian ini sesuai permasalahannya yaitu penyelesaian wicara melalui Peradilan oleh MUDP Provinsi Bali adalah tergolong 
dalam penelitian normatif yaitu penelitian yang dilakukan dengan mengkaji peraturanperaturan hukum yang ada. Sedangkan pendekatan yang dilakukan adalah pendekatan konseptual.

Penelitian ini menggunakan bahan hukum primer, bahan hukun sekunder dan bahan hukum tersier. Bahan hukum primer berupa Undang-Undang Dasar Negara Republik Indonesia (UUD NRI) Tahun 1945, Undang-Undang Nomor 39 Tahun 1999 Tentang Hak Asasi Manusia ( Selanjutnya disebut UU HAM), Undang-Undang Nomor 32 Tahun 2004 tentang Pemerintahan Daerah (selanjutnya disebut UU PEMDA), Perda Desa Pakraman, Anggaran Dasar Majelis Desa Pakraman Bali Tahun 2004 (selanjutnya disebut AD/ART MDP Bali), Keputusan Majelis Utama Desa Pakraman Nomor 050/Kep/Psm-1/MDP Bali/III/2006 tentang Hasil-hasil Pasamuhan Agung I MDP Bali, Keputusan Majelis Utama Desa Pakraman (MDP) Bali Nomor : 01/Kep/ Psm-2/MDP Bali/X/2007 tentang Hasil-hasil Pasamuhan Agung II MDP Bali. Sedangkan Bahan Hukum sekunder yang digunakan adalah pandangan, doktrin para sarjana yang terdapat dalam literature maupun artikel yang membantu pemahanam bahan hukum primer, termasuk pula bahan hukum tersier seperti kamus dan bahan dari internet.

\section{HASIL DAN PEMBAHASAN}

\subsection{Dasar Hukum Kewenangan}

Penyelesaian Perkara Adat Oleh Majelis Utama Desa Pakraman (MUDP) Provinsi Bali

Desa Pakraman adalah KMHA yang diakui oleh Negara. Pengakuan tersebut termuat dalam Pasal 18 B Ayat (2) UndangUndang Dasar Negara Republik Indonesia
Tahun 1945. Selain itu pengakuan atas hakhak traditionalnya juga dihormati sebagai bentuk identitas budaya dan hak masyarakat sebagaimana ditegaskan dalam Pasal 28I ayat (2 Pasal 18 B Ayat (2) Undang-undang dasar Negara Republik Indonesia Tahun 1945.

Selain konstitusi, Pasal 2 ayat (9) UU PEMDA juga menyebutkan pengakuan dan penghormatan Negara terhadap kesatuankesatuan masyarakat hukum adat beserta hak-hak tradisionalnya sepanjang masih hidup dan sesuai dengan perkembangan masyarakat dan prinsip NKRI. Ketentuanketentuan sebagai pengakuan Negara atas Kesatuan Masyarakat Hukum Adat melandasi terbitnya Perda Desa Pakraman.

Pasal 16 ayat (1) butir c Perda Desa Pakraman menegaskan tentang tugas Majelis Desa Pakraman yang menyebutkan "Majelis Desa Pakraman mempunyai tugas melaksanakan setiap keputusan-keputusan Paruman Majelis dengan aturan-aturan yang ditetapkan”. Berdasarkan kewenangan MUDP Provinsi Bali yang ternyata diperoleh dari peraturan perundang-undangan dalam menyelesaikan wicara yang ada maka sudah nyata dan jelas bahwa MUDP Provinsi Bali mendapat kewenangan secara delegasi ${ }^{5}$ dari Perda Desa Pakraman.

\footnotetext{
Kewenangan yang diperoleh dari konstitusi secara atribusi, delegasi, maupun mandat.Atribusi menunjuk pada kewenangan yang asli atas dasar konstitusi (UUD), delegasi ditegaskan sebagai pelimpahan wewenang kepada organ pemerintahan yang lain dan mandat bertindak atas nama pemberi mandat (Baca : F.A.M. Stroink dalam Abdul Rasyid Thalib, 2006, Wewenang Mahkamah Konstitusi dan Aplikasinya dalam Sistem Ketatanegaraan Republik Indonesia, Citra Aditya Bakti, Bandung, hlm.219).
} 


\subsection{Kewenangan Otonom Majelis Utama Desa Pakraman (MUDP) Dalam Penyelesaian Wicara}

Majelis Desa Pakraman (MDP) Provinsi Bali dibentuk oleh seluruh Desa Pakraman pada hari Sukra (Jumat) Wage, wuku Krulut, Isaka Warsa 1925, tanggal 27 Februari 2004, di Wantilan Pura Samuan Tiga, Desa Pakraman Bedulu, Kecamatan Blahbatuh, Kabupaten Gianyar, dengan demikian Majelis Desa Pakraman adalah derivasi Desa-Desa Pakraman yang dibentuk oleh masyarakat, dalam hal ini adalah masyarakat hukum adat Bali. Kewenangan Desa Pakraman yang telah dikukuhkan dalam Pasal 6 Perda Desa Pakraman. Kewenangan inilah yang diderivasikan kepada Majelis Desa Pakraman melalui Pasamuhan Agung maupun Paruman Agung. ${ }^{6}$

Selain pengakuan dari negara yang dijamin dalam konstitusi, Desa Pakraman juga memiliki hak otonom dalam menyelesaikan permasalahan yang terjadi sebagaimana diatur dalam Pasal 6 Ayat (1) dan Ayat (2) UU HAM terkait pengakuan KMHA memiliki hak asasi manusia, yang wajib dilindungi dan diperhatikan oleh hukum, masyarakat, dan Pemerintah, bahkan juga identitas budayanya serta hak atas tanah ulayat yang dimiliki didalamnya.

Khusus di Provinsi Bali, dengan adanya Perda Desa Pakraman sebenarnya sudah memperlihatkan adanya kepastian hukum terhadap Hak Otonomi ${ }^{7}$ tersebut. Sedangkan Majelis Desa Pakraman (MDP), demi mewujudkan penyelesaian wicara sebagai hak otonom Desa Pakraman maka

Pasal 1 Angka 16 Perda Desa Pakraman menegaskan bahwa "Paruman agung adalah sidang utusan prajuru desa pakraman se-Bali yang mempunyai kekuasaan tertinggi di Propinsi” telah mengeluarkan 2 (dua) buah Keputusan, antara lain :

1. Keputusan MUDP Nomor 050/Kep/ Psm-1/MDP Bali/III/2006 tentang Hasil-hasil Pasamuhan Agung I MDP Bali, pada Lampiran III butir 2 : "MDP di semua tingkatan secara berjenjang berkewenangan menyelesaikan persengketaan adat yang tidak berhasil diselesaikan di tingkat kerta desa/ prajuru desa di Desa Pakraman".

2. Keputusan MUDP Nomor : 01/Kep/ Psm-3/MDP Bali/X/2010 tentang Hasil Pasamuhan Agung MDP Bali Tahun 2010 yang menyatakan adanya Program Unggulan, antara lain :

Butir 4 :

"Mengoptimalkan peran dan fungsi Desa Pakraman beserta jajaran Majelis Desa Pakraman dalam menyelesaikan kasus-kasus adat berdasarkan hukum adat Bali."

Butir 5 :

"Memperjuangkan penyelesaian wicara yang telah diselesaikan oleh Desa Pakraman dan jajaran MDP Bali supaya mendapat legitimasi lembaga peradilan Negara."

Dalam kaitan ini, seperti yang di kemukakan Dharmayudha dalam Windia, bahwa istilah otonom atau otonomi, semula berarti peraturan sendiri atau mempunyai hak atau kewenangan untuk membuat peraturannya sendiri. Kemudian istilah otonom tersebut berkembang menjadi pemerintahan sendiri (Baca : Wayan P.Windia, 2004, Pecalang Perangkat Keamanan Desa Pakraman di Bali, LPM Universitas Udayana, Denpasar, hlm.31). 
Berdasarkan sifat otonom tersebut maka dapat dinilai bahwahukummemberikan pengertian yang jelas dan tegas berupa ${ }^{8}$ :

1) Bahwa semua hal yang terkait dengan permasalah adat murni di Bali yaitu yang bukan termasuk ranah hukum Pidana, juga bukan termasuk ranah hukum Perdata umum, dan bukan juga dalam unsur Tata Usaha Negaranya, maka kewenangan untuk menyelesaikan dan/atau sekaligus memutus berada secara otonom pada Desa Pakraman (DP) dan seterusnya sampai pada Majelis Utama Desa Pakraman (MUDP) Bali.

2) Bahwa Majelis Desa Pakraman, adalah Lembaga Adat yang dibentuk dari sifat otonom Desa Pakraman sehingga bukanlah merupakan Lembaga Tata Usaha Negara. Dan Prajuru (Pengurus) Desa Pakraman maupun Majelis Desa Pakraman dalam semua tingkatan bukanlah Pejabat Tata Usaha Negara. Dengan demikian Putusan-Putusan Desa Pakraman, Putusan-Putusan Majelis Desa Pakraman, dan PutusanPutusan Majelis Utama Desa Pakraman bukanlah Putusan Tata Usaha Negara

3) Bahwa Majelis Utama Desa Pakraman (MUDP) Bali sebagai Lembaga Tertinggi masyarakat hukum adat Bali tidak memiliki lembaga atasan sehingga Keputusan-Keputusannya

Penjelasan ini juga pernah disampaikan oleh Majelis Utama Desa Pakraman sebagai Tergugat dalam perkara sengkata Semita-Mulung (Gianyar) akibat adanya Surat Keputusan (SK) Nomor 003/ktps/ MDP/ BALI/IV/2007, tertanggal 11 April 2007 tentang Pemekaran Banjar Mulung menjadi Desa Pakraman Mulung (Baca : Putusan Pengadilan Tinggi Tata Usaha Negara Surabaya Nomor 85/B/2012/PT.TUN. SBY, tertanggal 10 September 2012, Jo. Putusan Pengadilan Tata usaha Negara Denpasar Nomor : 05/ G/2012/PTUN DPS, tanggal 8 Mei 2012). bersifat final dan mengikat semua krama (warga) adat beserta Lembaga Adat Bali yang bersangkutan.

Dengan memperhatikan dasar hukum hukum yang ada dimaa selain diatur dalam Peraturan Perundang-Undangan juga terdapat hukum yang buat oleh Desa Pakraman sendiri, maka Desa Pakraman termasuk sebagai kelompok sosial yang memiliki kemampuan untuk mengatur rumah tangganya sendiri. Desa Pakraman adalah social field (kelompok sosial) mempunyai kapasitas untuk membentuk hukumnya sendiri (self-regulation) yang disertai dengan kekuatan memaksa agar ditaati. ${ }^{9}$

\subsection{Analisa Kewenangan MUDP Provinsi Bali Dalam Menyelesaikan Wicara Melalui Peradilan}

Eksistensi Desa Pakraman mendapat pengakuan dalam peraturan perundangundangan di Indonesia termasuk dalam kewewenangannya untuk menyelesaikan kasus adat murni yang terjadi dalam lingkungan wilayahnya agar terbina kerukunan dan toleransi antar warga masyarakat. Dengan demikian maka kewenangan MDP Provinsi Bali dalam menangani dan menyelesaikan wicara adat Bali dalam kaitan ini merupakan derivative dari kewenangan Desa Pakraman yang diputuskan melalui Paruman dan/atau Pasamuhan Agung. ${ }^{10}$

Sally Falk Moore, 1983. Law and Social Change: The Semi-Autonomous Social Field as an Appropriate Subject of Study, Law as a process, an Anthropological approach, Routledge and Kegan Paul, London, hlm.78.

10 AD/ART MDP Bali, pasal 22 (3) huruf f menyebutkan, bahwa "Paruman Agung sebagai pemegang kekuasaan tertinggi berwenang menetapkan keputusan dan ketetapan lainnya yang dianggap perlu”, 
PeraturanDaerahtermasukdiakuidalam heirarki peraturan perundang-undangan. Khusus untuk masalah penyelesaian kasuskasus adat, kewenangan MUDP Provinsi Bali terdapat dalam Pasal 16 Ayat (2) Angka (2) Perda Desa Pakraman, Namun ternyata kemudian, MDP Provinsi Bali tidak hanya menjadi penengah saja, tetapi juga sebagai pemutus dalam perkara adat.

Dalam Pasal 16 ayat (1) butir c Perda Desa Pakraman yang menyebutkan "Majelis Desa Pakraman mempunyai tugas melaksanakan setiap keputusan-keputusan Paruman Majelis dengan aturan-aturan yang ditetapkan”, maka ditentukan bahwa MUDP Provinsi Bali berhak untuk menjalankan hasil - hasil Paruman MDP Provinsi Bali. Kemudian pada Keputusan MUDP Nomor 050/Kep/Psm-1/MDP Bali/III/2006 tentang Hasil-hasil Pasamuhan Agung I MDP Bali, pada Lampiran III butir 2 : "MDP di semua tingkatan secara berjenjang berkewenangan menyelesaikan persengketaan adat yang tidak berhasil diselesaikan di tingkat kerta desa/prajuru desa di Desa Pakraman", ternyata Desa Pakraman melalui MUDP Provinsi Bali berhak melakukan peradilan kalau dikehendaki oleh para pihak yang bersengketa. Dengan demikian pula kemudian MUDP Provinsi Bali lalu melakukan penyelesaian wicara melalui peradilan.

Dari Pasamuhan Agung I MDP Bali itulah kewenangan untuk mengadili wicara itu muncul, sehingga letak dari pemberian kewenangan menyelesaikan perkara adat untuk MUDP Provinsi Bali bukanlah berasal dari peraturan perundang - undangan atau delegasi dari konstitusi, melainkan dari hak otonom yang dimiliki oleh Desa Pakraman. Dalam hal ini, Desa Pakraman memberi kekuasaan kepada MUDP Provinsi Bali untuk mengatur teknis peradilannya. Hal ini berarti Desa Pakraman telah memberikan mandat kepada MDP Provinsi Bali untuk menyelesaikan wicara melalui peradilan.

Negara telah memberikan perlindungan dan pengakuan terhadap masyarakat adat ${ }^{11}$ baik melalui peraturan perundang-undangan maupun implementasi hak yang diterima oleh masyarakat adat, walaupun dasar pengakuan secara hukumnya berbeda dari hukum negara, namun sebenarnya tidak ada perbedaan pokok antara hukum negara dan hukum rakyat. Bahkan sebenarnya hukum negara dan hukum adat saling melengkapi untuk pembangunan hukum.

\subsection{Proses Penyelesaian Perkara Adat Melalui Peradilan Oleh Majelis Utama Desa Pakraman (MUDP) Provinsi Bali}

\subsubsection{Cara Penyelesaian Wicara Melalui Majelis Utama Desa Pakraman (MUDP) Provinsi Bali}

Penyelesaian wicara melalui MUDP Provinsi Bali diatur dalam Keputusan Majelis Utama Desa Pakraman Bali Nomor : 002/ Skep/MDP Bali/IX/2011 tentang Petunjuk Pelaksanaan dan Petunjuk Teknis Penyelesaian Wicara oleh Majelis Desa Pakraman (MDP) Bali. Dalam petunjuk pelaksana penyelesaian wicara, penyelesaian wicara dapat dilakukan dengan cara kekeluargaan melalui perundingan langsung para pi-

Masyarakat Adat adalah sebagai kelompok masyarakat yang memiliki asal usul leluhur (secara turun temurun) di wilayah geografis tertentu, serta memiliki sistem nilai, idiologi, ekonomi, politik, budaya, sosial, dan wilayah sendiri (Baca : Panitia Adhoc I DPD RI, 2009, Naskah Akademi Rancangan Undang-Undang Tentang Perlindungan Masyarakat Adat, Materi Uji Sahih, Dewan Perwakilan Daerah Republik Indonesia, hlm.91). 
hak yang terlibat dan wicara, penyelesaian wicara secara perdamaian dengan perantaraan (mediasi) pihak ketiga, baik perorangan maupun lembaga lain atau Majelis Desa Pakraman (MDP) sesuai jenjang, dan Penyelesaian wicara dengan diserahkan kepada Majelis Madya Desa Pakraman (MMDP) untuk mendapatkan keputusan. Kalau di MMDP tidak apat menyelesaikan wicara yang ada, maka wicara akan diselesaikan oleh MUDP Provinsi Bali melalui peradilan agar mendapat keputusan.

Penyelesaian wicara tersebut mengadung konsekuensi yuridis moral terhadap pihak yang mawicara. Yuridis moral tersebut adalah lahir dari asas - asas yang ada dalam penyelesaian wicara $^{12}$ Dalam penyelesaian wicara dengan cara kekeluargaan para pihak dituntut untuk memiliki itikad baik dan niat yang kuat untuk menyelesaikan wicara yang dihadapi. Para pihak senantiasa menjaga hubungan dan komunikasi, walaupun dalam alternative yang ditawarkan diberikan peluang untuk tawarmenawar. Disinilahkemudiandiadakan kesepakatan untuk tidak mempublikasikan suasana atau substansi pembicaraan baik secara langsung maupun tidak langsung, sebelum hasil resmi diperoleh.

Salah satu persyaratan adalah para pihak diwajibkan untuk menyiapkan

\footnotetext{
Penyelesaian wicara patut senantiasa memperhatikan dan mempertimbangkan tiga asas yaitu Pertama : Kalasyaan, yaitu diterima secara tulus ikhlas oleh pihak yang mawicara, Kedua : Kasujatian, yaitu kondisi objektif yang dihadapi oleh masyarakat. Ketiga : Kapatutan, yaitu kebaikan berdasarkan hukum adat Bali dan awig-awig Desa Pakraman baik tertulis maupun tidak tertulis (catur dresta) yang sesuai dengan perkembangan zaman dan nilai-nilai agama Hindu (baca : Keputusan Majelis Utama Desa Pakraman Bali Nomor : 002/Skep/MDP Bali/IX/2011 Tentang Petunjuk Pelaksanaan dan Petunjuk Teknis Penyelesaian Wicara oleh Majelis Desa Pakraman (MDP) Bali).
}

juru bicara yang tidak dapat diganti kecuali dalam hal mendadak seperti sakit, meninggal dunia atau dihentikan oleh pihak yang menghendakinya, sehingga mengenai waktu, tempat, substansi pembahasan sangat penting untuk disepakati. Namun yang paling penting dalam penyelesaian wicara melalui kekeluargaan adalah ketaatan terhadap asas (satya) untuk melaksanakan kesepakatan yang telah dibuat, yang pada hakekatnya kesepakatan tersebut diakhiri dengan matur piuning (upacara mohon ijin kepada dewata) kalau selesai. Matur piuning tersebut merupakan wujud penyelesaian secara niskala (sesuatu tidak terlihat).

Tugas Bandesa (pemimpin adat) dalam mediasi juga sangat penting dalam penyelesaian wicara. Tugas bendesa dibedakan menjadi 2 yaitu tugas Bandesa MUDP ketika pihak lain sebagai perantara (mediator) dan ketika sebagai Bandesa MUDP yang menjadi perantara (mediator). Pada akhirnya tugas mediator adalah menemukan solusi atas wicara yang terjadi, karenanya penting kemudian dilakukan sebuah pemahaman terlebih dahulu mengenai kedudukan mediator sebelum dilakukannya mediasi yang harus dituangkan dalam pernyataan.

Setelah terjadi pemahaman dan akhirnya sepakat untuk menyelesaikan wicara melalui keputusan MUDP Provinsi Bali, baru kemudian pihak yang menghendaki penyelesaian wicara melalui memutus oleh MUDP Provinsi Bali membuat permohonan kepada MUDP Provinsi Bali. Dalam Petunjuk Pelaksana Tata Cara Penyelesaian Wicara, Keputusan Majelis Utama Desa Pakraman Bali Nomor :002/Skep/MDP Bali/ IX/2011 diatur cara pengajuan permohonan penyelesaian wicara secara diputuskan 
MDP,yaitu :

(1) melampirkan penyelesaian oleh Bandesa Desa Pakraman dan MDP sesuai jenjang;

(2) melampirkan kronologis peristiwa dan/atau pokok permasalahan;

(3) mengajukan tawaran penyelesaian dan dasar pertimbangan penyelesaian;

(4) tembusan kepada Bandesa Pakraman setempat dan/atau pihak-pihak yang mawicara.

Syarat-syarat tersebut harus dipenuhi terlebih dahulu sebelum dilakukannya tahapan-tahapan dan pedoman dalam penyelesaian wicara melalui peradilan oleh MUDP Provinsi Bali.

\subsubsection{Hukum Acara Penyelesaian Wicara oleh MUDP Provinsi Bali}

Tahapan-tahapan tersebut dikenal dengan dudonan (tahapan) dan pedoman. Dudonan dan Pedoman tersebut merupakan hukum acara peradilan di MUDP Provinsi Bali. Pedoman Pasukertan Sabha Kerta MDP Provinsi Bali diatur dalam Lampiran 4 Keputusan Majelis Utama Desa Pakraman Bali Nomor : 002/Skep/MDP Bali/ IX/2011.

Tahapan pemeriksaan (Panureksan) oleh Panureksa diawali dengan matur piuning dengan banten pejati di ruang Panureksan yang dikemudian barulah dapat dibuka oleh pimpinan pemeriksan yang disebut Manggala Panureksa, dengan menyatakan dibuka atau tertutup bagi umum, yang ditandai dengan pengetokan palu. Manggala Panureksa wajib untuk meminta penjelasan identitas yang mewakili pihak yang mawicara. Pihak-pihak yang mewakili tersebut haruslah prajuru (pengurus) desa atau krama desa (warga desa) setempat yang mipil (tercatat) di Desa Pakraman yang bersangkutan setelah identitas para pihak jelas barulah kemudian dijelaskan terlebih dahulu tata tertib pemeriksaan berdasarkan petunjuk pelaksana dan petunjuk teknis (juklak-juknis) tata cara penyelesaian wicara dimana juklak-juknis tersebut dilakukan oleh panyarikan (sekretaris) Panureksa.

Hal yang paling awal dilakukan adalah selambat-lambatnya sehari sebelum Pasukertan Sabha Kerta dilakukan harus disiapkan terlebih dahulu mengingatkan anggota Sabha Kerta untuk hadir dalam pasukerta, menyiapkan berkas wicara beserta dengan lampirannya. Menyiapkan ruang pasukertan sesuai dengan format juklak-juknis Pasukertan Sabha Kerta dan menyiapkan konsumsi dan administrasi lain secukupnya karena pasukertan bisa terjadi secara marathon.

Pasukertan dipimpin oleh Bandesa MUDP Provinsi Bali dengan tahapan : sebelum Pasukertan Sabha Kerta dimulai, terlebih dahulu diawali dengan matur piuning dengan banten pejati pada tempat yang patut ruang Pasukertan, barulah kemudian pimpinan Pasukertan memeriksa daftar hadir dan mencocokkan dengan jumlah anggota Sabha Kerta dan Panureksan yang hadir dimana yang hadir sudah kourum maka barulah kemudian Pasukertan dibuka atau tertutup untuk umum.

Setelah hal tersebut terpenuhi maka pedoman selanjutnya adalah penjelasan kronologis Panureksan dan Paruman Panureksan dimana hasilnya selanjutnya diberikan kepada Sabha Kerta. Barulah kemudian Sabha Kerta berwenang untuk memeriksa, mempelajari, menilai dan 
mengambil keputusan atas wicara yang dihadapi.

Setelah memeriksa, mempelajari, menilai dan mengambil keputusan, dilakukan Pasukertan untuk memutuskan dan menyepakati keputusan yang diambil Sabha Kerta dengan putusan yang ditandatangani oleh seluruh anggota Sabha Kerta Dan ditandai dengan ketok palu 3 (tiga) kali.

Dengan adanya juklak-juknis yang dibuat MUDP Provinsi Bali, maka memperlihatkan MUDP Provinsi Bali ingin sekali membuat hukum acara peradilan yang cepat, sederhana dan biaya ringan. Istilah pemeriksaan pembuktian dalam peradilan tersebut dinamakan Panureksan yang berarti pemeriksaan, sedangkan pemeriksanya sendiri disebut dengan Panureksa. Peradilan untuk mendapat keputusan oleh MUDP Provinsi Bali sendiri dinamakan Sabha Kerta. Dan untuk persidangannya dinamakan Pasukertan. Istilah-istilah tersebut merupakan ciri kekhasan yang dimiliki peradilan di dalam MUDP Provinsi Bali, yang juga membuktikan adanya sifat otonomi dari Desa Pakraman yang menjelma dalam MUDP Provinsi Bali.

\subsubsection{Analisa Terhadap Penyelesaian Wicara Melalui Peradilan Oleh MUDP Provinsi Bali}

Sebuah peradilan MUDP Provinsi Bali semata-mata untuk menunaikan tugas dan wewenang yang diamanatkan dalam Pasal 16 Perda Desa Pakraman. Ketika Desa Pekraman memiliki permasalahan yang kemudian menjadi perkara adat murni (wicara) maka reaksi adat merespon untuk mengembalikan keadaan menjadi seimbang. Selanjutnya ajaran memutus, bahwa suatu perselisihan tidak mungkin digarap secara penyelesaian, sehingga perlu adanya suatu langkah yang bersifat tegas dan jelas dengan tidak usah menghawatirkan konsekwensikonsekwensi yang timbul tentang kembali tidaknya keadaan semula yang telah terganggu. ${ }^{13}$

Penyelesaian wicara acara memutus adalah penyelesaian yang diambil berupa peradilan dimana para pihak adalah pihak yang bersengketa menyerahkan segala keputusannya kepada pihak III untuk mengadili dan mengakhiri tunuk kepada keputusan tersebut dan melaksanakan keputusan tersebut maka harusnya para pihak harus mengetahui dan menerapkan asas Kalasyaan, Kasujatian dan Kapatutan yang ditetapkan dalam Keputusan MUDP Bali Nomor : 002/Skep/MDP Bali/IX/2011 Tentang Petunjuk Pelaksanaan dan Petunjuk Teknis Penyelesaian Wicara oleh Majelis Desa Pakraman (MDP) Bali.

Dari segala ketentuan maupun mekanisme atau hukum acara penyelesaian wicara tersebut peradilan oleh MUDP Bali yang ada, MUDP sebagai tingkatan tertinggi dari MDP Provinsi Bali telah memberikan sebuah kepastian bahwa Desa Pekraman telah memiliki cara sendiri dalam menyelesaikan wicara. Oleh karena penyelesaian wicara telah ditugaskan kepada MUDP Bali melalui Keputusan MUDP tentang hasil-hasil Pasamuhan Agung I MDP Bali.

Hal yang perlu dicermati dalam keputusan tersebut adalah adanya permohonan dari MUDP Bali untuk dukungan dan pengamanan keputusan, yang ternyata menjadi hal yang sangat penting. Dukungan dan pengamanan keputusan

Moh.Koesno, 1979, Catatan-Catatan Terhadap Hukum Adat Dewasa Ini, Surabaya, Airlangga University Press, hlm.49. 
ditujukan lembaga lain seperti pemerintahan dinas (non adat) untuk membantu MUDP Bali. Hal ini memperlihatkan keputusan tersebut sebenarnya tidak dapat dieksekusi oleh MUDP Bali apabila tidak ditaati. MUDP Bali sangat ketergantungan dengan ketaatan para pihak terhadap asas-asas peradilan di MUDP Bali yang berlaku pada para pihak. Dampak negatif dari permohonan tersebut adalah otonomi desa pakraman dapat tergradasi oleh karena masuknya pihak di luar adat yang dengan dalih pengamanan atau menegakkan keputusan MUDP tetapi ternyata memperlihatkan intervensi pada sikap otonom Desa Pakraman.

Dalam sebuah sistem peradilan, ujung dari peradilan itu sendiri adalah sebuah eksekusi. Kalau permasalahan tersebut terjadi pada internal Desa Pakraman, maka tentunya Desa Pakraman dapat menggerakkan satuan pengamanan seperti pacalang untuk melaksanakan Keputusan yang dibuat oleh Desa Pakraman kalau ternyata yang dikenakan putusan melakukan perlawanan. Sangat berbeda halnya dengan MDP Bali yang merupakan sebuah lembaga adat yang lahir bukan sebagai Kesatuan Masyarakat Hukum Adat (KMHA). Sehingga penting kemudian ketika Keputusan tersebut akan diberlakukan nantinya dilakukan oleh Para pihak yang berwicara secara sungguhsungguh. Menjadi persoalan ketika ternyata Keputusan MUDP Bali tersebut mendapat penolakan dari Pihak yang merasa dirugikan, bahkan MUDP Bali dapat menjadi pihak yang digugat. Oleh karena itu, legitimasi MUDP Bali ketika terjadi penolakan terhadap keputusan yang timbul akan dipertaruhkan.

MUDP Bali sebagai lembaga pembuat keputusan dalam sebuah wicara memerlukan pranata untuk melegitimasikan keputusan yang telah dibuat kepada para pihak yang berwicara. Pranata tersebut adalah sebuah badan kelengkapan bagi Sabha Kerta MUDP Bali, yang bertugas untuk mengawal setiap Keputusan yang dihasilkan. Dalam hal ini menurut peneliti seharusnya dibentuk sebuah lembaga yang termasuk dalam kelembagaan MUDP Bali untuk melakukan eksekusi semacam juru sita pada Pengadilan Umum.

Kekhawatiran terhadap akibat penolakan para pihak yang merasa dirugikan dapat diantisipasi dengan membentukan lembaga pendukung sebuah keputusan. Bagi pihak yang dirugikan tentunya harapan untuk mendapat keputusan yang adil tidak terpenuhi dalan Peradilan oleh MUDP Bali. Oleh Karena itu, selain pencegahan perlawanan dari pihak yang merasa dirugikan dengan cara membuat keputusan yang baik, juga harus disertai dengan penanggulangan berupa sebuah lembaga eksekusi dari MUDP Bali.

\section{PENUTUP}

\subsection{Kesimpulan}

Dari keseluruhan uraian pembahasan tersebut, akhirnya dapat diambil suatu kesimpulan sebagai berikut :

1. Bahwa kewenangan yang diperoleh MUDP Provinsi Bali untuk menyelesaikan wicara melalui peradilan diperoleh secara mandat berdasarkan Keputusan MUDP Nomor 050/Kep/Psm-1/MDP Bali/III/2006 tentang Hasil-hasil Pasamuhan Agung I MDP Bali. Perda Desa Pakraman tidak secara tegas mengatur tentang kewenangan MUDP Provinsi Bali dalam menyelesaikan wicara melalui peradilan, namun dalam Pasal 16 Ayat (1) butir c menentukan bahwa 
Majelis Desa Pakraman (MDP) Bali mempunyai tugas untuk melaksanakan setiap keputusan-keputusan Paruman Majelis dengan aturan-aturan yang ditetapkan, lalu Desa Pakraman melalui Paruman Agung I pada tanggal 27 Februari 2014 memberikan kewenangan kepada Majelis Desa Pakraman untuk menyelesaikan wicara dengan cara memutus atau melalui peradilan, sehingga kewenangan MUDP Bali dalam menyelesaikan wicara melalui peradilan merupakan mandat yang diberikan oleh Desa Pakraman.

2. Proses penyelesaian wicara didahului dengan adanya permohonan dari pihak yang mawicara dengan memenuhi terlebih dahulu konsekuensi dan persyaratan yang ditetapkan oleh MUDP Bali. Setelah diterima baru kemudian Bandesa Agung MUDP Bali menetapkan Tim Panureksa, Tim Panureksa inilah yang kemudian memeriksa berkas yang ada, setelah selesai dilakukan pemeriksaan baru kemudian Panureksa membuat rekomendasi kepada Sabha Kerta MUDP Provinsi Bali, yang pada akhirnya Sabha Kerta MUDP Provinsi Bali membuat keputusan untuk menyelesaikan wicara yang ada. Peradilan oleh MUDP Provinsi Bali telah diatur sedemikian rupa berdasarkan dalam Keputusan Majelis Utama Desa Pakraman Bali Nomor : 002/Skep/MDP Bali/IX/2011 Tentang Petunjuk Pelaksanaan dan Petunjuk Teknis Penyelesaian Wicara oleh Majelis Desa Pakraman (MDP) Bali sebagai bentuk otonomi yang dimiliki oleh Desa Pakraman. Namun ternyata dalam proses pelaksanaan keputusan yang dibuat, MUDP Bali tidak memiliki lembaga eksekusi yang berwenang untuk mengeksekusi keputusan yang dibuat sehingga MUDP Provinsi Bali memerlukan bantuan dari pihak di luar adat untuk membantu dan mengamankan pelaksanaan keputusan MUDP Provinsi Bali tersebut ketika terjadi penolakan.

\subsection{Saran}

Berdasarkan uraian dari pembahasan serta kesimpulan yang telah disampaikan, akhirnya dapat dikemukakan beberapa saran-saran sebagai berikut :

1. Pasal 1 Ayat (3) UUD NRI Tahun 1945 menegaskan bahwa Indonesia merupakan Negara Hukum, sehingga segala kewenangan harus diatur secara hukum. Perda Desa Pakraman tidak mengatur secara tegas kewenangan yang dimiliki MUDP Provinsi Bali untuk menyelesaikan wicara secara peradilan, untuk itu secara hukum perlu memperjelas status kewenangan otonom Desa Pakraman dengan merevisi Peraturan Daerah tentang Desa Pakraman, dengan menambah ketentuan tentang kewenangan MDP Bali untuk menyelesaikan wicara baik melalui mediasi maupun melalui peradilan.

2. Dalam sebuah lembaga peradilan diperlukan lembaga eksekusi untuk mengeksekusi keputusan yang di telah dibuat. MUDP Provinsi Bali ternyata tidak memiliki lembaga eksekusi untuk melaksanakan keputusan yang dibuat, sehingga memerlukan bantuan dari 
pihak di luar adat untuk melaksanakan keputusan MUDP Provinsi Bali. Bantuan dari pihak luar adat untuk mengeksekusi keputusan adat sama saja dengan intervensi terhadap otonomi desa adat yang ada untuk itu diperlukan lembaga eksekusi untuk pelaksanaankeputusanMUDPProvinsi Bali. Dengan demikia penting untuk membentuk dan menguatkan lembaga adat yang bertugas untuk melakukan eksekusi terhadap Keputusan MUDP Bali.

\section{DAFTAR BACAAN}

DPD RI, Panitia Adhoc I, 2009, Naskah Akademi Rancangan UndangUndang Tentang Perlindungan Masyarakat Adat, Materi Uji Sahih, Dewan Perwakilan Daerah Republik Indonesia

Koesno, Moh, 1979, Catatan-Catatan Terhadap Hukum Adat Dewasa Ini, Surabaya, Airlangga University Press, hal. 49

Majelis Desa Pakraman, 2012, Purwaka Tata Cara Penyelesaian Wicara Oleh Majelis Desa Pakraman (MDP) Bali Cet-I, Majelis Utama Desa Pakraman (MUDP) Bali, Denpasar.

Moore, Sally Falk, 1983. Law and Social Change : The Semi-Autonomous Social Field as an Appropriate Subject of Study, Law as a process, an Anthropological approach, Routledge and Kegan Paul, London.

PutusanPengadilanTinggiTataUsahaNegara Surabaya Nomor 85/B/2012/PT.TUN. SBY, tertanggal 10 September 2012, Jo. Putusan Pengadilan Tata usaha
Negara Denpasar Nomor : 05/G/2012/ PTUN DPS, tanggal 8 Mei 2012)

Stroink, F.A.M. dalam Abdul Rasyid Thalib, 2006, WewenangMahkamahKonstitusi dan Aplikasinya dalam Sistem Ketatanegaraan Republik Indonesia, Citra Aditya Bakti, Bandung

Surpha, I Wayan, 1993, Eksistensi Desa Adat di Bali, Penerbit PT. Upada Sastra, Denpasar.

Windia, Wayan P, 2004, Pecalang Perangkat Keamanan Desa Pakraman di Bali, LPM Universitas Udayana, Denpasar.

\section{DAFTAR PERATURAN}

\section{PERUNDANG-UNDANGAN}

Undang-Undang Dasar Negara Republik Indonesia Tahun 1945

Undang-Undang Nomor 39 Tahun 1999 Tentang Hak Asasi Manusia

Undang-Undang Nomor 32 Tahun 2004 tentang Pemerintahan Daerah

Peraturan Daerah Provinsi Bali Nomor 3 Tahun 2001 tentang Desa Pakraman sebagaimana telah diubah dengan Peraturan Daerah Provinsi Bali No.3 Tahun 2003 tentang Perubahan Atas Peraturan Daerah Provinsi Bali Nomor

3 Tahun 2001 tentang Desa Pakraman Keputusan Majelis Utama Desa Pakraman Nomor 050/Kep/Psm-1/MDP Bali/ III/2006 tentang Hasil-hasil Pesamuhan Agung I MDP Bali)

Keputusan Majelis Utama Desa Pakraman (MDP) Bali Nomor : 01/Kep/Psm-2/ MDP Bali/X/2007 tentang Hasil-hasil Pasamuhan Agung II MDP Bali

Keputusan Majelis Utama Desa Pakraman Bali Nomor : 002/Skep/MDP Bali/ IX/2011 Tentang PetunjukPelaksanaan 
Gurnal ISSN 2302-528X

Magister Hukum Udayana • Desember 2015

Vol. 4, No. 4 : 700 - 712

(UDAYANA MASTER LAW JOURNAL)

dan Petunjuk Teknis Penyelesaian

Wicara oleh Majelis Desa Pakraman

(MDP) Bali)

Anggaran Dasar/Anggaran Rumah

Tangga (AD/ART) MDP Bali. 